\title{
PENGARUH LIFESTYLE TERHADAP KEPUTUSAN PEMBELIAN KOSMETIK WARDAH DI KOTA JAMBI
}

\author{
Dahmiri' $^{1)}$, Husni Hasbullah ${ }^{2)}$, Siska Sefrita Sari ${ }^{3)}$ \\ ${ }^{1,2,3)}$ Prodi Manajemen FEB Universitas Jambi \\ Siskasefrita12@gmail.com
}

\begin{abstract}
Abstrak
Penelitian ini bertujuan untuk menganalisis pengaruh Lifestyle terhadap keputusan pembelian Kosmetik Wardah di kota jambi. Penelitian ini menggunakan pendekatan kuantitatif. Sampel dalam penelitian ini adalah 49 orang konsumen Wardah yang pernah membeli produk Waradah. Instrumen penelitian ini menggunakan kuesioner online dan dianalisis menggunakan alat analisis Regresi Linear Berganda. Hasil penelitian ini menunjukan bahwa pengaruh lifestyle terhadap keputusan pembelian kosmetik wardah di kota jambi memiliki pengaruh yang signifikan terhadap keputusan pembelian kosmetik wardah di kota jambi. Aktivitas, minat dan opini mempengaruhi keputusan pembelian konsumen sebesar 89,7\% dan sisanya sebesar 10,3\% yang dipengaruhi oleh faktor lain yang tidak diteliti dalam penelitian ini. Variabel minat adalah variabel yang dominan dalam mempengaruhi keputusan pembelian kosmetik wardah. Hasil dari penelitian ini juga menunjukan bahwa rata-rata tanggapan dari setiap responden mengenai aktivitas, minat, opini dan keputusan pembelian masuk dalam kategori baik.
\end{abstract}

Kata kunci : Lifestyle, Keputusan Pembelian

\begin{abstract}
This study aims to analyze the influence of Lifestyle on Wardah Cosmetics purchasing decisions in Jambi City. This study uses a quantitative approach. The sample in this study were 49 Wardah consumers who had purchased Waradah products. This research instrument used an online questionnaire and was analyzed using a Multiple Linear Regression analysis tool. The results of this study indicate that the influence of lifestyle on wardah cosmetics purchase decisions in jambi city has a significant influence on wardah cosmetics purchase decisions in jambi city. Activities, interests and opinions influence consumer purchasing decisions by $89,7 \%$ and the remainder by 10,3\% which is influenced by other factors not examined in this study. Interest variable is the dominant variable in influencing wardah cosmetic purchasing decisions. The results of this study also showed that the average response of each respondent regarding activities, interests, opinions and purchasing decisions included in both categories.
\end{abstract}

Keywords: Lifestyle, Purchasing Decisions

\section{PENDAHULUAN}

Dalam menghadapi persaingan pemasaran yang semakin tajam, seorang produsen tidak boleh terpaku pada bentuk produk yang menawarkan manfaat dasarnya saja. Persaingan sekarang bukanlah apa yang diproduksi perusahaan dalam pabrik tetapi antara apa yang mereka tambahkan pada hasil pabrik tersebut dalam bentuk pengemasan, iklan, konsultan bagi pelanggan, pendanaan, pengiriman, pergudangan dan hal-hal lainnya yang dipandang perlu. Dengan demikian keberhasilan menjual suatu produk sangat ditentukan oleh keterampilan mengelola produk inti (core product), produk tambahan (Augmented 
product) dan produk yang disempurnakan yang berbeda dari pesaingnya. Sebagaimana diungkapkan Levitt dalam Kotler (2007:449).

Salah satu industri pasar yang saat ini mengalami persaingan yang ketat dalam kegiatan memasarkan produknya guna memperebutkan konsumen adalah industri pasar kosmetik. Munculnya ancaman bisnis baru di bidang kosmetik menyebabkan perusahaan harus mengembangkan dan merebut pangsa pasar. Salah satu produk yang kosmetik yang saat ini sedang berupaya untuk merebut pangsa pasar adalah produk kosmetik Wardah.

Banyaknya merek krim kosmetik wajah yang ada, menyebabkan konsumen berpindah dari satu merek ke merek lainnya. Sehingga perusahaan dituntut untuk lebih kreatif dan inovatif dalam memasarkan produknya agar dapat bersaing dengan produk lain. Pada tingkat persaingan yang rendah, merek hanya sekedar membedakan antara suatu produk dengan produk lainnya. Sedangkan pada tingkat persaingan yang tinggi, merek memberikan kontribusi dalam menciptakan dan menjaga daya saing sebuah produk.

Demikian terjadi pada perusahaan kosmetik di Indonesia, khususnya produk kecantikan wardah. Dengan banyaknya perusahaan kosmetik yang ada di Indonesia, maka konsumen akan lebih selektif dalam menentukan merek kosmetik yang digunakan sebagai alat kecantikan. Munculnya berbagai produsen kosmetik dari luar negeri semakin memperketat persaingan industri kosmetik di Indonesia. Keputusan konsumen dalam menentukan atau memilih merek kosmetik tertentu bukanlah hal yang begitu saja terjadi. Banyak pertimbangan yang dilakukan konsumen sebelum memutuskan untuk membeli suatu produk misalnya, harga, kualitas prouk dan iklan. Data penjualan kosmetik di Indonesia selama dua tahun terakhir tahun 2017-2018 mengalami kenaikan dan penurunan. Terdapat 3 produk kosmetik yang bersaing ketat untuk merebut pangsa pasar, yaitu Revlon, Maybelline dan Wardah. Adapun data Market Share Krim Kosmetik wajah di Indonesia dapat dilihat pada tabel berikut : (Engel,2016).

Tabel 1.1.

Data Market Share Kosmetik wajah di Indonesia Tahun 2017-2018

\begin{tabular}{|l|c|c|}
\hline \multirow{2}{*}{ Merek } & \multicolumn{2}{|c|}{ Tahun } \\
\cline { 2 - 3 } & $\mathbf{2 0 1 7}$ & $\mathbf{2 0 1 8}$ \\
\hline Pond's & $42.8 \%$ & $44,3 \%$ \\
\hline Wardah & $8,0 \%$ & $7,3 \%$ \\
\hline Sariayu & $7,0 \%$ & $7,2 \%$ \\
\hline Garnier & - & $7,0 \%$ \\
\hline Pipa & $6,4 \%$ & $6,6 \%$ \\
\hline Citra & $3,8 \%$ & $4,0 \%$ \\
\hline Olay & $3,7 \%$ & $3,7 \%$ \\
\hline Nivea & $3,0 \%$ & $3,0 \%$ \\
\hline
\end{tabular}

Sumber : topbrand index 2017, topbrand index 2018 (www.topbrand-award.com).

Berdasarkan Tabel 1.1 menunjukkan peringkat penjualan beberapa produk kosmetik yang sering digunakan oleh konsumen dari tahun 2017 sampai tahun 2018. Dapat dilihat bahwa dua tahun berturut krim kosmetik Pond's merupakan pemimpin pasar dengan market share terbesar, yakni 43,8\% pada tahun 2017 dan 44,3\% pada tahun 2018. Produk kosmetik Wardah sendiri mengalami penurunan market share dari tahun 2017 ke tahun 2018 yaitu dari $8 \%$ menjadi 7,3\%. Kondisi ini menjadi perhatian yang sangat penting bagi produsen kosmetik Wardah untuk menjadikan produknya unggul di pasaran dan 
perusahaan harus membuat inovasi baru agar menarik perhatian konsumen untuk membuat keputusan pembelian.

Hal ini memberikan sebuah transisi teknologi khususnya dalam bidang promosi dan pemasaran pada umumnya. Para pelaku usaha banyak yang melakukan penyelidikan ataupun penjajakan dengan pemanfaatan internet sebagai senjatanya dalam upaya memenuhi kebutuhan demi kepentingan bisnisnya. Fenomena yang ada seperti ini dapat mempengaruhi dalam dunia maya yang mengalami perubahan yang sangat cepat, terutama pada perilaku dan gaya hidup konsumen berbelanja. Masyarakat tidak hanya berbelanja di offline shop, namun juga banyak yang menggemari berbelanja di online shop yang dianggap lebih hemat tenaga dan lebih praktis. Banyak juga toko-toko offline yang juga mempromosikan barangnya melalui toko online. "Perubahan perilaku supplier atau konsumen menjadi salah satu pendorong perubahan dalam bidang strategi pemasaran yang dilakukan perusahaan" (Tjahjono, dkk., 2011:54).

Facebook, Twitter dan Instagram merupakan media sosial yang masih diminati oleh pelaku usaha untuk menyampaikan pesan ataupun informasi mengenai produk kepada konsumen dan calon konsumennya. Teknologi internet sudah semakin banyak dimanfaatkan oleh berbagai organisasi terutama organisasi bisnis. Pekerjaan online kini semakin diminati, terutama pada pengusaha-pengusaha yang mempromosikan barangnya lewat online. Mengingat jumlah penggunaannya yang cukup tinggi di Kota Jambi, kini jejaring sosial memainkan peran yang signifikan dalam proses pemasaran produk ( Assauri, 2010:15)

Kosmetik wardah memanfaatkan social media instagram dan facebook untuk melakukan pemasaran produknya dengan cara beriklan di media sosial dan mengunduh foto produk yang akan ditampilkan untuk membagikan informasi produk kepada pengikutnya. Dari perkembangan yang sangat pesat antusias pengguna media sosial lebih cepat tanggap dan nyaman dalam melakukan proses pembelian karena konsumen dapat melihat semua produk baru yang ditawarkan. Selain itu, beberapa merek kosmetik telah hilang dari pasar karena tidak dapat bersaing dengan kompetitor sejenis (Daud, dkk, 2015:53).

Semakin banyaknya produk pesaing maka konsumen dihadapkan dengan banyak pilihan, hal ini menuntut perusahaan untuk menciptakan inovasi. Sebuah inovasi tidak akan berarti jika produk tidak memiliki diferensiasi dari produk pesaingnya. Diferensiasi produk bagi sebuah perusahaan sangatlah penting karena dengan adanya diferensiasi maka akan tercipta awareness sebuah produk. Sebuah produk memiliki sebuah diferensiasi selain untuk menciptakan awareness atau kesadaran, diferensiasi dilakukan oleh perusahaan agar perusahaan dapat mempertahankan eksistensinya. Salah satu diferensiasi sebuah produk adalah dapat dilihat pada kemasan produk. Kemasan menjadi pembeda yang paling cepat diingat oleh konsumen. Kemasan dapat membangun citra di benak konsumen, konsumen dapat dengan cepat memilih produk yang diinginkan. Oleh karena menarik untuk melakukan penelitian dengan judul : Pengaruh Lifestyle Terhadap Keputusan Pembelian Kosmetik Wardah Di Kota Jambi.

Masalah yang diangkat dalam penelitian ini adalah Apakah lifestyle berpengaruh signifikan baik secara parsial maupun simultan terhadap keputusan pembelian konsumen pada kosmetik Wardah di Kota Jambi dan Variabel mana dari dimensi Gaya Hidup (Lifestyle) yang berpengaruh dominan terhadap keputusan pembelian kosmetik wardah di Kota Jambi. 


\section{TINJAUAN PUSTAKA}

Pemasaran (marketing) banyak didefenisikan dalam arti luas, salah satu defenisi menyatakan bahwa, pemasaran terdiri dari kegiatan perorangan dan organisasi yang memudahkan dan mempercepat hubungan pertukaran yang memuaskan dalam lingkungan yang dinamis melalui penciptaan, pendistribusian, promosi dan penentuan harga barang, jasa serta gagasan (Leod, 2011:34).

Proses pemasaran banyak berhubungan dengan konsumen, yang dipengaruhi oleh informasi. Bahkan dunia pemasaran tidak dapat hidup tanpa adanya informasi, apapun bentuk informasi tersebut. Apabilah dalam era jejaring sosial seperti saat ini, telah terjadi pergeseran paradigma pemasaran. Dari pemasaran tradisional (offline), kepemasaran modern (online) yang dilakukan untuk melakukan pemasaran suatu produk atau jasa melalui atau menggunakan media internet. Internet merupakan salah satu penemuan yang mutakhir di era globalisasi di bidang teknologi informasi sangat menguntungkan semua manusia di seluruh dunia untuk berbagi informasi dan komunikasi, termasuk berbagai produk, barang dan jasa yang dijual (Hermawan, 2012:45).

\section{Gaya Hidup (Lifestyle)}

Gaya hidup menurut Yuniarti (2015:154) dapat mempengaruhi perilaku seseorang dan pada akhirnya menentukan pilihan-pilihan konsumsi seseorang. Pengertian gaya hidup menurut Setiadi (2013:80) adalah cara hidup yang diidentifikasikan oleh bagaimana seseorang menghabiskan waktu mereka (aktivitas), apa yang mereka anggap penting dalam lingkungannya (ketertarikan), dan apa yang mereka pikirkan tentang diri mereka sendiri.

Gaya Hidup (Lifestyle) Gaya hidup menurut Yuniarti (2015:154) dapat mempengaruhi perilaku seseorang dan pada akhirnya menentukan pilihan-pilihan konsumsi seseorang. Pengertian gaya hidup menurut Setiadi (2013:80) adalah cara hidup yang diidentifikasikan oleh bagaimana seseorang menghabiskan waktu mereka (aktivitas), apa yang mereka anggap penting dalam lingkungannya (ketertarikan), dan apa yang mereka pikirkan tentang diri mereka sendiri. Lifestyle menggambarkan keseluruhan diri seseorang dalam beriteraksi dengan lingkungannya (Kotler dan Armstrong, 2012:154).

\section{Keputusan Pembelian}

Keputusan pembelian menurut Alma (2010:32) adalah suatu keputusan konsumen yang dipengaruhi oleh ekonomi keuangan, teknologi, politik, budaya, produk, harga, lokasi, promosi, physical evidence, people dan process, sehingga membentuk suatu sikap pada konsumen untuk mengolah segala informasi dan mengambil kesimpulan berupa response yang muncul produk apa yang akan dibeli. "Keputusan pembelian adalah tahap dalam proses pengambilan keputusan pembeli di mana konsumen benar-benar membeli. Konsumen bebas memilih produk yang diinginkan sesuai dengan kebutuhannya, memutuskan tempat pembelian, bagaimana caranya, banyak pembelian, kapan membeli, dan mengapa harus membeli. Konsumen membeli dan mengonsumsi produk bukan sekedar karena nilai fungsi awalnya, namun juga karena nilai sosial dan emosionalnya Jadi, Keputusan pembelian, adalah pemilihan satu dari dua atau lebih alternatif pilihan keputusan pembelian, artinya bahwa seseorang dapat membuat keputusan, haruslah tersedia beberapa alternatif pilihan (Kotler \& Armstrong, 2012:214).

Swastha dan Handoko (2014:106) menyatakan bahwa perilaku konsumen akan menentukan proses pengambilan keputusan dalam pembeliannya. Proses tersebut merupakan sebuah pendekatan penyelesaian masalah yang terdiri atas lima tahap yaitu: 
menganalisa atau pengenalan kebutuhan dan keinginan, pencarian informasi dan penilaian sumber-sumber, penilaian dan seleksi terhadap alternatif pembelian, keputusan untuk membeli, dan perilaku sesudah pembelian. Konsumen melalui lima tahap dalam proses keputusan pembelian antara lain pengenalan masalah, pencarian informasi, evaluasi alternatif, keputusan pembelian, dan perilaku pasca pembelian" (Kotler dan Keller, 2009:184).

Adapun dimensi keputusan pembelian :

a. Pencarian Informasi

Proses pengambilan keputusan pembelian dimana konsumen telah tertarik untuk mencari lebih banyak informasi

b. Minat

Setelah memperoleh informasi, pembeli mulai menumbuhkan minat atau keinginan atas barang tersebut.

c. Evaluasi alternatif

Proses pengambilan keputusan pembelian dimana konsumen menggunakan informasi untuk melakukan evaluasi atas berbagai pilihan

d. Keputusan pembelian

Proses pengambilan keputusan pembelian dimana konsumen benar-benar membeli produk.

\section{Hubungan Lifestyle dan Keputusan Pembelian}

Gaya hidup (lifestyle) merupakan pola kehidupan seseorang yang diwujudkan dalam aktivitas (pekerjaan, hobi, berbelanja, olahraga, kegiatan sosial), minat (makanan, mode, keluarga, rekreasi) dan opini yang lebih dari sekedar kelas sosial dan kepribadian seseorang (Laksana, 2017:13)

Menurut Kotler, Armstrong (2003:224), hubungan lifestyle dan proses pengambilan keputusan pembelian terdiri dari lima tahap, yaitu: pengenalan kebutuhan, pencarian informasi, pengevaluasian alternatif, keputusan pembelian, dan perilaku setelah pembelian. Jelas bahwa proses pembelian berlangsung jauh sebelum pembelian aktual dan berlanjut jauh sesudahnya. Keputusan pembelian barang atau jasa seringkali melibatkan dua pihak atau lebih. Umunya ada lima peranan yang terlibat. Kelima peran tersebut meliputi:

a. Pemrakarsa (initiator), yaitu orang yang pertama kali menyarankan ide untuk membeli suatu barang atau jasa.

b. Pembawa pengaruh (influencer), yaitu orang yang memiliki pandangan atau nasihat yang mempengaruhi keputusan pembelian.

c. Pengambil keputusan (decider), yaitu orang yang menentukan keputusan pembelian

d. Pembeli (buyer), yaitu orang yang melakukan pembelian secara nyata

e. Pemakai (user), yaitu orang yang mengkonsumsi dan menggunakan barang atau jasa yang dibeli.

\section{METODE PENELITIAN}

\section{Populasi dan Sampel}

Menurut Sugiyono $(2008 ; 8)$, populasi adalah wilayah geberalisasi yang terdiri atas objek atau subjek yang mempunyai kualitas dan karakteristik tertentu yang ditetapkan oleh peneliti untuk dipelajari dan kemudian ditarik kesimpulannya. Populasi penelitian ini adalah pembeli atau pengguna produk kosmetik wardah dan owner wardah di Kota Jambi pada Tahun 2019 sebanyak 98 orang. Sampel menurut Sugiyono (2011:8) adalah bagian 
dari jumlah karakteristik yang dimiliki oleh populasi tersebut. Untuk menentukan ukuran sampel dari suatu populasi terdapat bermacam-macam pendapat ahli. Dalam menetapkan besarnya ukuran sampel penulis mengacu pada rumus berikut Slovin (Umar, 1997:78)

\section{Sumber Data}

Jenis data yang digunakan dalam penelitian ini adalah data primer. Data primer merupakan data yang diperoleh secara langsung dari pengguna media sosial. Untuk memperoleh informasi secara langsung dari responden, maka dilakukan dengan cara membagikan kuisioner kepada, responden. Kuisioner ditujukan kepada responden yang minimal sudah memiliki media sosial.

\section{Analisis dan Alat analisis Data}

Dari hasil kuisioner, data menggunakan model skala likert dengan 5 alternatif jawaban kepada responden. Selanjutnya data dianalisis menggunakan pendekatan regresi linear berganda.

\section{Variabel Penelitian}

Variabel Independen yaitu :

$\mathrm{X}=$ Lifestyle (Gaya Hidup)

$\mathrm{X} 1=$ Aktivitas

$\mathrm{X} 2=$ Ketertarikan

$\mathrm{X} 3=$ Opini

Variabel Dependen yaitu : $\mathrm{Y}=$ keputusan pembelian

\section{HASIL DAN PEMBAHASAN \\ Karekteristik Responden}

Karakteristik responden penelitian ini dibagi menjadi 3 bagian yaitu, berdasarkan pelanggan, berdasarkan lama berlangganan dan berdasarkan pendapatan. Penelitian ini menunjukan bahwa yang menjadi responden dalam penelitian ini adalah distributor, reseller dan konsumen pemakai dengan jumlah sebanyak distributor 4 orang atau sebanyak $4 \%$, reseller sebanyak 6 orang atau $6 \%$ dan konsumen pemakai terbanyak sebesar 40 orang atau $40 \%$. Untuk responden berdasarkan lama berlangganan nampak bahwa sebagian besar lama berlangganan responden yang terbesar dalam penelitian ini adalah 2-5 tahun yakni sebanyak 2 orang atau sebesar $2 \%$, kemudian disusul lama berlangganan antara $<1$ tahun yakni sebanyak 28 orang atau $28 \%$, sedangkan yang terakhir adalah lama berlangganan > 5 tahun yakni sebanyak 2 orang atau $2 \%$. Sehingga dapat disimpulkan bahwa pelanggan yang terdiri dari distributor, reseller dan konsumen pemakai yang membeli kosmetik wardah rata-rata lama berlangganan adalah di 2 - 5 tahun.

Berdasarkan tingkat pendapatan yaitu memberikan gambaran mengenai tingkat pendapatan yang dimiliki responden, dengan perincian pendapatan dibawah dari Rp.1000.000,- juta, 5 juta - 10 juta dan pendapatan di atas dari 12 juta. nampak bahwa sebagian besar pendapatan responden dalam penelitian ini adalah di atas dari 2 juta yakni sebanyak 25 orang atau sebesar 58,3\%, kemudian disusul oleh responden yang mempunyai pendapatan antara 1juta - 1.5 juta yakni sebanyak 19 orang atau 31,7\%, sedangkan yang terakhir adalah responden yang mempunyai pendapatan dibawah dari 500.000 ,- yakni sebanyak 6 orang atau sebesar 10\%. Sehingga dapat disimpulkan bahwa konsumen yang membeli kosmetik wardah rata-rata mempunyai pendapatan di atas dari 2 juta. 


\section{Uji Statistik}

Hasil uji validitas dari seluruh variabel penelitian menunjukkan kondisi valid, dengan $r$ tabel ( 0,238). Sama dengan itu, uji reliabilitas menggunakan Cronbach's Alpha lebih besar dari 0,6. Berdasarkan hasil uji reliabilitas maka dapat dilihat bahwa variabel aktivitas reliabel dikarenakan nilai Cronch Alpha > 0,6. 3 variabel lainnya riliabel yaitu variabel minat dengan nilai Cronch Alpha 0,961 > 0,6, opini dengan nilai Cronch Alpha $0,970>0,6$ dan keputusan pembelian dengan nilai Cronch Alpha 0,962 > 0,6.

\section{PEMBAHASAN}

Berdasarkan hasil penelitian dan pembahasan tentang pengaruh lifestyle terhadap keputusan pembelian kosmetik wardah dikota jambi dapat disimpulkan bahwa Berdasarkan hasil penelitian dapat disimpulkan karakteristik responden yang paling lama menggunakan kosmetik wardah dikota jambi yaitu responden dengan lama waktu 2-5 tahun atau sebesar $50 \%$, dengan total pendapatan terbesar diatas 2 juta atau sebesar $58,3 \%$. Dilihat dari hasil kuesioner berdasarkan perhitungan uji statistik t, disimpulkan bahwa lifestyle (aktivitas, minat dan opini) secara persial berpengaruh terhadap keputusan pembelian kosmetik wardah di kota jambi. Dilihat dari kuesioner berdasarkan perhitingan $\mathrm{R}$ Square, dapat disimpulkan bahwa aktivitas, minat dan opini mempunyai distribusi terhadap keputusan pembelian kosmetik wardah dikota jambi sebesar 89,7 \% sedangkan sisanya $10,3 \%$ dipengaruhi oleh beberapa faktor lain yang tidak diteliti oleh peneliti.

\section{SIMPULAN DAN SARAN}

Adapun kesimpulan dari penelitian ini adalah sebagai berikut :

1. Di antara variabel aktivitas, minat dan opini secara persial variabel minat yang paling dominan dalam mempengaruhi keputusan pembelian kosmetik wardah di kota jambi.

2. Dilihat dari kuesioner berdasarkan perhitingan $\mathrm{R}$ Square, dapat disimpulkan bahwa aktivitas, minat dan opini mempunyai distribusi terhadap keputusan pembelian kosmetik wardah dikota jambi sebesar 89,7 \% sedangkan sisanya 10,3\% dipengaruhi oleh beberapa faktor lain yang tidak diteliti oleh peneliti.

Adapun saran yang dapat disamapaikan adalah sebagai berikut :

1. Produsen kosmetik wardah sebaiknya memperbaiki dan meningkatkan elemen-elemen aktivitas, minat dan opini yang dianggap baik pelaksanaanya oleh konsumen, sehingga faktor-faktor tersebut mampu mempengaruhi keputusan pembelian, maka dari itu akan muncul ide baru yang inovatif dan beragam sesuai dengan harapan konsumen.

2. Kosmetik wardah sebaik nya dapat mempertahankan kualitas dan mutu dan lifestyle menjadi pertimbangan, karna selama ini konsumen kosmetik wardah dari berbagai macam aktivitas sehingga kondisi tersebut seharusnya menjadi acuan dalam mempromosikan produk agar lebih terkenal. Sehingga semakin baik lifestyle konsumen maka konsumen mencari produk yang semakin bermutu dan berkualitas terutama untuk kosmetik yang dipakainya. yang diterapkan produsen kosmetik wardah maka semakin tinggi kecendrungan konsumen untuk memutuskan keputusan pembelian.

3. Bagi penulis selanjutnya, diharapkan dapat meneliti pada kelompok responden yang belum diteliti dalam penelitian ini dan dapat meneliti lebih luas dan jelas lagi tentang lifestyle. 


\section{DAFTAR PUSTAKA}

Adhellia Anggia Puspita Yusanti (2017). Pengaruh Marketing Mix, Celebrity Endorsment, dan Lifestyle Terhadap keputusan pembelian kosmetik wardah. Jurnal: Sekolah Tinggi Ilmu Ekonomi Indonesia (STIESIA) Surabaya

Adisaputro, Gunawan. (2010). Manajemen Pemasaran: Analisis Untuk Perancangan Strategi Pemasaran. Yogyakarta: YKPN.

Anita B Wandanaya (2011). Pengaruh Pemasaran Online Terhadap Keoutusan Pembelian Produk. Jurnal: Jurusan Teknik Informatika, STMIK Raharja.

Angel (2016). Market Share Krim Kosmetik wajah di Indonesia Tahun 2017-2018.

Alma, B. (2010). Manajemen Pemasaran dan Pemasaran Jasa. Alfabeta. Bandung

Assauri, S. 2010. Manajemen Pemasaran. PT. Rajagrafindo Persada. Jakarta.

Daud, I dan M. E. Fitrianto (2015). Peran Celebrity Endorser Dalam Membentuk Perceive Value Dan Purchasing Intention. Jurnal Manajemen dan Bisnis Sriwijaya. 13(3): 359-376.

Dinggon, M. R., B. Lumanauw, dan I. Trang. (2015). Pengaruh Bauran Pemasaran, Celebrity Endorsment Dan Gaya Hidup Terhadap Keputusan Pembelian Smartphone Samsung Galaxy Pada Mahasiswa Feb Unsrat Manado. Jurnal Emba. 3(3): 1370-1382.

Harly, G. S dan D. Octavia (2014). Pengaruh Endorsement Fashion Blogger Terhadap Minat Beli Merek Lokal Pada Tahun 2013 - 2014 (Studi Kasus Pada Fashion Blogger Evita Nuh). Jurnal Manajemen Indonesia. 14(2): 1-13.

Hermawan, Agus (2012). Komunikasi Pemasaran. Jakarta: Erlangga

Istijanto (2009). Aplikasi Praktis Riset Pemasaran, Jakarta: Gramedia Pustaka Utama

Karismajid Nur Laksana, 2017. Gaya Hidup, Kelas Sosial dan Keputusan Pembelian Produk Sepatu Impor Pada Kalangan Mahasiswa (Studi Pada Mahasiswa Dan Mahasiswi Fakultas Ekonomi Dan Bisnis Universitas Brawijaya Malang). Jurnal: Fakultas Ekonomi dan Bisnis. Universitas Brawijaya Malang. 